\title{
BUSINESS CHALLENGES OF COVID-19 PANDEMIC AND POTENTIAL STRATEGIES OF SUSTAINABILITY IN NIGERIA MARITIME SECTOR
}

\author{
Ikenna Amuka ${ }^{1 \mathrm{i}}$, \\ Ozumba Uzochukwu', \\ Nnamdi Chijoke Anyachebelu ${ }^{3}$ \\ Institute of Maritime Studies, \\ University of Nigeria, \\ Enugu Campus, \\ Nigeria
}

\begin{abstract}
:
Maritime transport is the foundation of global supply chain connections and economic development with shipping and ports estimated to manage more than 80 per cent of world merchandise trade by volume and over 90 per cent by value, according to United Nation Conference on Trade and Development (UNCTAD) 2020. Consequently, when severed covid-19 pandemic occur, there are absolute disruption of transport networks and supply chain which hugely undermined international trade and economic activity. The covid-19 pandemic activates health and economic crisis with extensive consequences for maritime transport and trade. Restrictions imposed in response to the covid-19 pandemic have triggered disruptions affecting economic activity and trade in maritime sector which includes ports operations, shipping and supply chains. The strategic measures taken to control the spread of the corona virus disease and slowdown of economic activity and trade have significantly affect the maritime sector both locally and globally. Thus, the study assesses the impacts of covid-19 pandemic in business operations of Nigeria maritime sector. Hence, this study analyzes the sustainable response to get back to business fully in Nigeria maritime trade. This study was performed by reviewing the available published literatures, case studies, and various government and non-government agencies/organizations from reports and official websites, served as the frameworks of the study. From huge compilation of relevant studies, presentation of data and information which is vital to maritime business challenges of covid-19 pandemic and potential strategies of sustainability and meet study objectives.
\end{abstract}

JEL: R40; R42; L20

i Correspondence: email ikenna.amuka@unn.edu.ng 
Keywords: Covid-19; maritime sector; economic activity; sustainability

\section{Introduction}

The dramatic global economic shutdown caused by covid-19 is having pervasive or significant adverse effects on jobs, economies, wealth creation and government. The oil and gas sector went one of the largest corrections in its history, due to reduction in economic activity and limited success by OPEC to curtail production. However, demand of oil and gas was significantly reduced and also traded below $\$ 5$, although it is seriously gaining momentum recently.

Economically, the effects of covid-19 have already been felt by Nigerians and other countries, because the demands for raw materials and goods from China has significantly reduced, and access to industrial components and produced commodities from China has been hampered. Consequently, there is already uncertainties in country with widespread geopolitical and economic instability. However, vaccines have been produced by many companies, but the major questions are how reliable is the vaccine? since some European countries have started declining from usage AstraZeneca covid-19 vaccine, because unconfirmed number of people developed blood clots after vaccinated. Another vital question is when will it get all? Especially to those people that reside in less developed countries.

Notably, more than $90 \%$ of the global trade in terms of value are moved by sea, the world maritime supply chain is considered serious. Like different economic sectors, various components of maritime industry have drastically impacted covid-19 pandemic. As result of the pandemic, many segments of maritime have been exposed and seems vulnerable in area of maritime networks, port efficiency, and hinterland connectivity. Thus, global shipping markets have been negatively affected with the slump in demand due to non-essential travel, a largely reduced workforce in factories and the closure of production and shipping facilities.

Nevertheless, fisheries, maritime transport, travel and tourism have been heavily impacted by covid-19 pandemic due to the restrictions on movement constituting curfews, lockdowns and stay-at-home policies. In addition to curtailing people's movement, these restrictions have disrupted the supply and demand chain of seafood products and led to other broken economic chains.

\section{Research Questions}

1) To what extent has Covid-19 pandemic affected the Nigeria maritime business operations?

2) What is the sustainable response to get fully back to business in maritime trade? 


\section{Literature Review}

\subsection{Challenges of Covid-19 in Maritime Industry}

The maritime trade flows at an unprecedented negative speed and scale. The virus hampered the global trade flow greatly and major operations have been partially suspended as a response to curb the spread of the virus. "UNTCAD estimates global merchandise trade to have fallen by 5 percent in the first quarter of 2020 and expects a deeper contraction of 27 percent in second quarter. For the full year, UNCTAD expects a drop of 20 percent" (UNCTAD,2020). The World Bank further noted that merchandise trade appeared to have bottomed but in April 2020, falling nearly 20 percent year on year, after a 10 percent decline in March 2020, the trade contraction caused by covid-19 is deeper than the one observed during the financial crisis of 2008-2009.

Figure 1: Trade contraction during Covid 19 pandemic

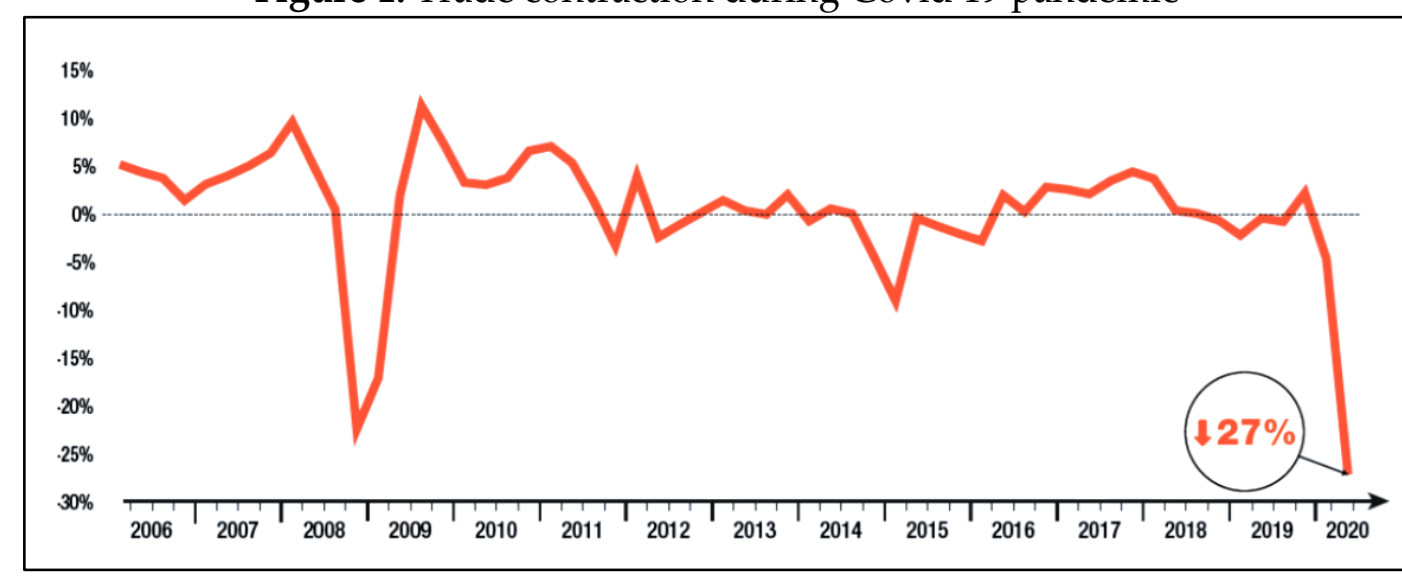

Source: UNCTAD (2020). Global Trade Update. June

(https://unctad.org/en/pages/newsdetails.aspx?OriginalVersionID=2392

Table 1: Global trade in 2020 (Percentage change over 2019)

\begin{tabular}{|l|c|c|c|c|}
\hline & \multicolumn{2}{|c|}{ Q1 2020 } & \multicolumn{2}{c|}{ April 2020 } \\
\hline & Import & Export & Import & Export \\
\hline Developed Countries & $-6 \%$ & $-3 \%$ & $-10 \%$ & $-14 \%$ \\
\hline Developing Countries & $-2 \%$ & $-7 \%$ & $-19 \%$ & $-18 \%$ \\
\hline South-South Trade & & $-2 \%$ & \multicolumn{2}{c|}{$-14 \%$} \\
\hline
\end{tabular}

Source: UNCTAD (2020). Global Trade Update. June

(https://unctad.org/en/pages/newsdetails.aspx?OriginalVersionID=2392).

Table 1 above shows decline in the export of developed and developing countries to $-3 \%$ and $-7 \%$ respectively. This might result reduced demand in destination markets, decreasing import are driven by the supposed demand as well as other factors such as exchange rate instability, concerning debt and shortage of foreign currency. Continued lockdown will increase rapid deterioration of trade in developing countries.

The maritime sector internationally has experienced serious bottlenecks and decreased revenue. Many countries are supporting the sector because of sets, for instance United Kingdom chamber of shipping placed an immediate demand for multi-million 
pound government support package to ensure the shipping industry can continue to bring in the food, commodities and medicines the country will need to fight the covid19. Nevertheless, Maritime Port Authority of Singapore (MPA) provided financial support to the maritime industry against the surge of the corona virus pandemic. To assist vessel owners and operators of cargo vessels, MPA stated that they will provide a $30 \%$ reduction in port dues for in port for cargo vessels during the period. MPA will also grant $30 \%$ concession on port dues for all non-passenger carrying harbor craft in the port of Singapore over the same period. In addition, regional ferry operators will be offered $50 \%$ rebate to offset their monthly rental fees for overnight vessel berthing.

Nevertheless, Nigeria Port Authority (NPA) suspends certain fees. NPA in line with global best practices, directed all terminal operators to suspend all applicable terminal storage fees on consignments, also known as demurrage for an initial period of 21 days. The NPA also stated that the gesture was in recognition of the pressure that the covid-19 pandemic imposes on businesses and responsibility imposed on the authority to relieve this burden on its customers.

Sometimes in June,2020, about 50 cargoes of Nigeria's crude oil were havouring around the world looking for buyers at very low rate. This is one the factors that shows there has been sharp decline in the volume of import and export cargoes and some retailers and manufacturers have failed to claim their cargoes and containers leaving the warehouses congested. More so, there are many jobs loses, retrenchment or job cuts in the maritime industry because of covid-19 pandemic. Numerous dock workers lose their jobs as employers in the industry are seeking cheaper labour as a means of cut costs. This trend is similar to 2016 depression when we experienced economic strife and many workers were laid off to tide companies. The Lagos chamber of commerce and industry published a report that stating that trillions of naira is lost as revenue annually due to the shortcomings of the ports in Nigeria.

\subsection{Major Issues that Hampered Maritime Transport due to Covid-19}

1) Crew fatigue and human error: This is a situation where port workers spend more time than they ordinary should on-board, jeopardizing their health and consequently, the ships safety.

2) Insurance claims and loses: "It is calculated that the greatest impact of loss from insurance claim will be felt in the cruise ship sector, due to owners' liability to passengers and crew" (Prosertek, 2020). This entail facing possible legal action in the event of outbreaks on-board or cancellations. Many claims might be filed with cargo ships would be due to delays in freight delivery. These are especially fatal for cargo that may be damaged or depreciated.

3) Safety hazards: "In this situation of greater operative precariousness for the sector, one great fear is that attempt will be made to reduce costs at the expense of safety. This could undo the years of progress in safety" (Prosertek, 2020). In this situation that ports are working skeletally or partially, could lead to delays in port inspection as well as 
response time to unforeseen circumstances or contingencies, worsening possible accidents such as fire collisions and running aground.

4) Cargo damage and delays: the impact or emergence of covid-19 disrupt transport cycle and structures globally. This led to cargoes stored at longer periods of time without adequate security and high risk of theft, loss, fire or inclement weather. However, delays can damage perishable or temperature-sensitive goods.

5) Maintenance problems and breakdowns: due to covid-19 lockdown, there is great risk in ship maintenance and repair. Interruptions in the supply of spare parts and other goods can lead to delays or use of materials of lower quality. This clearly increases the risk of machinery breakdowns, the cause behind one-third of sailing incidents.

\subsection{Possible Response and Strategic Measures to Contain Covid-19 in Maritime Sector}

"A response strategy plan requires first of all planning for the worst-case scenario that is how the crisis will evolve over time, which is the baseline to workout, what will be the biggest possible impact for the organization" (PWC, 2020). These pertinent questions should be considered in response measures and strategic sustainability.

- Does business expect that government measures will manage to contain the virus spread?

- Which locations are likely to come online and back to business first?

- How soon does management expect that travel and people gathering restrictions will be lifted?

- Does management expect the virus-spread to worsen in countries/regions which are key to their supply chain or the regions in which it operates?

"These assessment of the worst case is ongoing processes as the crisis continue to evolve and new insights and facts will become available" (PWC Greece, 2020).

\subsubsection{Strategic Response Plan in Ports}

International Maritime Organization (IMO) did a great job by declaring maritime activity as essential services amidst covid-19 pandemic ravaging. Consequently, ports operators will continue services and operation despite shutdown of economies. The essence of operation is to aid the evacuation essential items such as food, medical equipment and petroleum products. Although ports workers were allowed full operation, but global best measures must be properly applied to curb the spreading of the virus. There is some essential port operational adjustment for optimal performance amidst covid-19 pandemic.

Prioritization of the essential port activities which include freight transport and logistic chain to make the essential goods and services reach their destination without unnecessary delay and also curb the virus. Nevertheless, there are need to consider this prioritization as fast lane or speed lane, this mean that quick evacuation of medical cargo, 
food stuff and other kind of essential service which include oil production, fuel distribution etc. to the desired destination.

Another strategic plan to contain the virus spreading is religiously adhering to disease control center regulations, that is social distancing and sanitary protocol, such as the use of facemasks, regular washing of hands, use of hand sanitizer etc. In Nigeria, the Nigeria Center for Disease Control(NCDC) is body responsible to control the dreaded corona virus, and its main goal is to protect public health and prevention of communicable disease.

Many ports adopted the strategy of reorganization of their staff operation to allow them work for longer hours/shift changeover time due to both social distancing and need for cleaning equipment and operational vehicles must be observed. The organization operation team changes according to seize and type to ports and cargoes involved, rotational working approach can be used to avert congestion in ports and as well help to contain the spreading of covid-19.

Usage of digital documentation will limit human interface or contact to the minimum in ports. UNESCAP 2020, stated that "In addition to improving operational efficiency and reducing operating costs, digitalization helped ensure uninterrupted functions in the conditions of the reduced port personnel and the need to limit physical contacts".

\subsubsection{Strategic Response Plan in Shipping}

The global economy experienced unprecedented disruption due to covid-19 pandemic and shipping activity are not exempted. There are total or partial imposed lockdowns and movement restrictions of people, despite the difficult situation, shipping lines continue working under the global backing of International Maritime Organisation (IMO), that declares shipping operation as essential services. Immediately covid-19 pandemic erupted globally in January 2020, shipping companies adhere to instructions or directives of WHO, IMO and other National authorities to ensure health protection measures across their ships, infrastructure and offices. "Among the necessary measures introduced in some countries at the height of crisis, is the requirement of ships to be equipped with protection equipment such as hand sanitizer, gloves, and masks, new company policies restricted crew from mingling with people on shore at ports" (UNCTAD, 2020).

More so, shipping lines encourage operational flexibility and implementation of usual business plans to ensure that operations and services are not shutdown. This calls for continuation of operation while people avoided travel and observed confinement or social distancing rules. Some bigger shipping companies indulge in shifting functions to other offices and support centers in other regions through shared services etc.

Another main response to covid-19 pandemic effect is use of technology to work remotely. This calls for technological upgrade skills and knowledge as regards to both online conferencing and the efficient use of online workspace. Covid-19 challenges have made us known that there is need to invest more in digitalization for efficient and effective operation. "Digitalization such as documentation and booking processes, E-business 
tools and equipment online connectivity, rose as a key solution to increasing the resilience of the maritime supply chain and security business continuity during the crisis" (UNCTAD, 2020).

\subsection{Covid-19 Pandemic and Digitalization in Maritime Sector}

In line with a global trend, the covid-19 pandemic prompted accelerated digitalization in the public and private sector. It boosted the use of new technologies such as container terminal automation, use of new technologies of Big Data, Internet of Things, Digital Twin Technologies, 5G telecommunication network and Block-chain.

Yin Lam stated that "Maritime transport is the backbone of global economy, accounting for over $90 \%$ of cross-border trade. And like most other industries shipping is being rapidly transformed by a range of technology innovations that aim to make operations greener, cheaper and more efficient. At the same time the covid-19 pandemic has upended maritime transport and created unprecedented challenges for professionals across the sector". Digitalization has been significant for continue operation and services in maritime sector during covid-19 pandemic. On January 21,2021, World Bank and International Association of ports and Harbors launched a report that cooperation and collaboration between private and public sectors across the maritime supply chain will greatly enhance profits, safer and more resilient supply chain and lower emissions.

Makhtar Diop, World Bank Vice-President for Infrastructure, "Beyond immediate benefits to the maritime sector, digitalization will help countries participate more fully in the global economy, and will lead to better development outcomes". International Association of Ports and Harbors (IAPH) Managing Director of Policy and Strategy, Dr Patrick Verhoeven, added that "Digitalization is not just a matter of technology but, more importantly of change management, data collaboration, and political commitment".

The covid-19 pandemic has forced many firms to adopt new style of operation, just as affected people way of life and routine business. Maritime port and shipping business has become more forwarding-facing and better prepared for the future now. Numerous companies or sectors that has not engage on digitalization have understood that the analogue world and paper-based businesses are no longer a long-term option currently. Reducing risk of constant physical human to human contact and encourage paperless workflows is ideal pattern to fight the pandemic. The transaction of digitalization is moving a different speed across the business world, many ports and shipping lines companies are integrating new technology to its smart strategy into its operations and business via standardization, automation and digitalization. These practices will establish transparency, sustainability and best practices that seamlessly unifies its network. 


\section{Traditional and Smart Port}

Figure 2: Traditional and Smart Port

\begin{tabular}{|c|c|c|}
\hline TRADITIONAL PORT & & SMART PORT \\
\hline & Invoice format & $\ddot{*}$ \\
\hline Paper invoice & & Digital invoice \\
\hline$=1=$ & Truck driver terminal & 0 \\
\hline Paper emission ticket & & QR Code \\
\hline Notify by yard operators & $\begin{array}{l}\text { Container collection } \\
\text { point \& stand-by location }\end{array}$ & $\begin{array}{c}\text { Online reservation available and } \\
\text { real-time confirmation to pick up point }\end{array}$ \\
\hline $\begin{array}{l}\text { Direct call and SMS by terminal } \\
\text { operators }\end{array}$ & $\begin{array}{l}\text { Ad hoc logistics } \\
\text { and transportation } \\
\text { notification }\end{array}$ & $\begin{array}{c}\text { Real time apps and social media } \\
\text { platform }\end{array}$ \\
\hline$\infty$ & Payment methods & $=\$$ \\
\hline Mostly cash or COD & & Online e-payment \\
\hline
\end{tabular}

Source: Hutchison Port Holding Group 2020.

UNTAD 2020, established that "Port Community of Systems (PCS), Single Windows (SW) and other electronic exchange platforms, for example, have played a critical role during covid-19 pandemic crisis. Digital infrastructure has facilitated trade and cross border logistics by simplifying administrative and regulatory processes". Reports shows that companies with digital background or inclined excel and provide quality services as trusted third party.

\begin{tabular}{|c|c|c|}
\hline & $\begin{array}{l}\text { Short Term } \\
\text { Changes }\end{array}$ & $\begin{array}{l}\text { Potential Long Term/ } \\
\text { Structural Changes }\end{array}$ \\
\hline $\begin{array}{l}\text { Shipping } \\
\& \\
\text { Logistics }\end{array}$ & $\begin{array}{l}\text { - Decreased maritime changes } \\
\qquad \quad \text { Vulnerable in ports with low } \\
\text { trade volume due to fleet } \\
\text { adjustment including blank } \\
\text { sailing } \\
\text { - } \quad \text { Delayed customs and ports clearance } \\
\text { - } \quad \text { Increased ship waiting time and delaying } \\
\text { - } \quad \text { Relatively freight rates that could further } \\
\text { increased if capacity continue to be } \\
\text { constrained and demand/supply } \\
\text { mismatch occurs }\end{array}$ & $\begin{array}{ll}\text { - } & \text { Facilitated digitalization } \\
\text { - } & \text { Increased risk management costs } \\
\text { - } & \text { Intensified merger and acquisitions } \\
\text { - } & \text { Ind competition among companies } \\
\text { - } & \text { Supply chain reconfiguration and } \\
\text { design }\end{array}$ \\
\hline Ports & $\begin{array}{l}\text { - Increased workload due to the } \\
\text { quarantine and health controls } \\
\text { - } \quad \text { Increased volume volatility } \\
\text { - Shortage of container stacking yard } \\
\text { during congestion } \\
\text { - Slowdown of port economy }\end{array}$ & $\begin{array}{l}\text { Greater use of technology and digital } \\
\text { tools to smart port and automated } \\
\text { ports } \\
\text { - More focus on increasing resilience } \\
\text { and robustness of operations to }\end{array}$ \\
\hline
\end{tabular}




\begin{tabular}{|l|ll|l|}
\hline \hline & $\bullet \begin{array}{l}\text { Challenges to smooth inland transport } \\
\text { operations and hinterland connections }\end{array}$ & $\begin{array}{l}\text { wide-ranging risks, including from } \\
\text { pandemics }\end{array}$ \\
& $\begin{array}{l}\text { Changes in port calls and connectivity } \\
\text { - Challenges to yard operations to due to } \\
\text { peak port calls (i.e less frequent calls but }\end{array}$ & $\begin{array}{l}\text { Higher focus on port safety and } \\
\text { security } \\
\text { larger port call exchanges) }\end{array}$ & $\begin{array}{l}\text { Greater use of integrated transport } \\
\text { services and inland transport } \\
\text { operations }\end{array}$ \\
$\begin{array}{l}\text { Storage and warehousing capacity } \\
\text { constrains }\end{array}$ & $\begin{array}{l}\text { Supply chain reconfiguration and } \\
\text { design that may change port } \\
\text { network configuration }\end{array}$ \\
\hline
\end{tabular}

Source: Economic and social commission for Asia and the Pacific (ESCAP), 2020.

\subsection{New Normal and Back to Business}

With corona virus pandemic resulting to shutdown of businesses operations, people's movement and entire global economies which led to working adjustments, regulatory and operational conditions, masterminding back to business strategic plan as a procedure. It has been established that workers must adhere to new strategic plan on how make the work place a safe and secure environment. International Association of Ports and Harbors (IAPH) developed best practices of return-to-work directives, targeting to help ports globally overcome covid-19 challenges, by providing a menu of options base on best strategic approaches from ports internationally.

The IAPH methods on return to strategy are in four (4) annexes and they are as follows:

1) Protocol, with detailed procedures, prevention, guidance, return conditions, hygiene and social distancing measures.

2) Advice to personnel on what is expected from their side and how port protocols may change to adapt to new covid-19 conditions (i.e facemasks wearing, travelling to/from work, follow local legislative guidance, maintaining the operational environment etc.).

3) Suggestions advancing teleworking for limiting use of indoor meetings, visitors and/or external meetings as well as international travel and advanced sanitary measures such as testing and establishing partnership with testing labs.

4) Suggestions that detail procedures and practices:

- For port employee when entering and leaving port area and offices;

- For port employee mobility around the workplace;

- For shift patterns and working groups;

- For safe indoor and outdoor static workstations;

- Meetings;

- For commercial areas;

- For the facilitation of a positive workplace mina-set.

In order to adequately implement the aforementioned practices and approaches, a capacity building effort will be required. For instance, "UNCTAD Train For Trade Port Management Programme" (PMP) and other developments trainings that will enhance operation and services in maritime sector globally. 
In thriving for New Normal and Back to Business Operation, public policy initiatives will be essential. The policy will be proactive and must ensure safe, secure and sound working place and seamless operations.

\section{Methodology}

This study performed by reviewing business challenges of covid-19 pandemic and potential strategies of sustainability in maritime sector.

The researcher sourced and analysed results based on empirical reports derived from available literatures, works by other authors and scholars such as published journals, UNCTAD, IMO, NIMASA publications and other relevant materials.

Essential literatures review approach (method) was adopted as an empirical evidence on business challenges of covid-19 pandemic and potential strategies of sustainability in maritime sector.

\section{Results and Discussions}

Maritime transport encountered adverse business challenges because of covid-19 pandemic which led disruption of trade operations and working conditions. Many sanitary protocols/measures were strategically in place to bring back business fully, however, there were still deficiencies.

The outcomes of covid-19 forced Nigerian government to imposed lockdown on businesses and restrictions of people's movement. Thus, this dreaded disease led to loss of revenue in the sector, unexpected unemployment and loses of jobs, operational adjustments, disruptive of supply chain especially, essentially goods like food stuff, medical items, petroleum products etc.

Ports and shipping lines were able to diffuse several risks when they allowed for telecommuting, implementing sanitary protocols which includes, social distancing, use of face masks, regular use of hands sanitizers, regular washing of hands with running water, adjustment of working shifts/patterns, limited meetings and travelling, took advantage of relevant social policies and make greater use of new technology.

Shippers and ports have worked to restore operations fully, but the ability to adopt has not been always optimally. The major tools used curb this covid-19 pandemic issues are digitalization, increased communications and coordination with other stakeholders and public authorities.

The strategic measures to contain covid-19 challenges demands that all the stakeholders in sector must come together to collaborate and coordinate to combat risks and improved resilience for optimal performances.

The implications of covid-19 crisis could be long lasting, although the of connectivity did not deteriorated as anticipated early. According to UNCTAD 2020, a case study analyses revealed that there was decision to divert a single ship from some countries, the absence of a ship call, or even a single operator due to the reduction in 
cargo available at a destination key export markets, have put to test the ability of maritime transport to deliver essential goods.

In supporting going back to business, public policy initiative cannot be ignored. Already, there has been interesting concepts on ground initiated by various agencies in Nigeria maritime industry. Inasmuch there are many variations in response to action of covid-19 by different agencies/institutions, which includes economic and operational measures adopted, but there is need to align or harmonize policies to attain International Maritime Organization standards.

\section{Conclusion and Recommendations}

The maritime sectors are critical in the international and regional economy and social well-being. There are economic contraction and uncertainty have expanded due to covid19 pandemic. This has brought untold hardship, tragedy and economic pain; however, it has enabled ports, shipping lines and entire maritime industry to experience the practical benefits of modern technology in testing situations. This review has provided a timely and study to understanding some areas in maritime industries with practical insight. A concise review of challenges in maritime operation and management, impact of disruptions and possible response to be in full business.

This study recommend that required collaboration and coordination of all stakeholders to ensure the reorganization of operation and working conditions due to sanitary protocols.

Conclusively, there should digital transformation and technological solutions that ports and shipping operators will adopt to lay ground for a more efficient and effective future. There will be going back to old ways of doing business and further development of artificial intelligence and the internet of things will accelerate the pace of change towards a fully digital world.

\section{Conflict of Interest Statement}

The authors declare no conflicts of interests.

\section{About the Author}

Ikenna Amuka has broad experience in both academics and non-academics fields. He holds B.Sc (Economics); M.Sc (Development Studies); and MBA (Business Management). His wealth of knowledge and experience earned him a position as Research Fellow, and Lecturer in the Institute of Maritime Studies, University of Nigeria, Nsukka, Nigeria. 


\section{References}

Bakir Sahin et al. (2020). Effects of Covid-19 on Maritime: a review.

Deborah Oneil et al. (2020). How Covid-19 is Driving Maritime Organisation

ESCAP (2020). Covid-19 and its Impact on Shipping and Port Sector in Asia and the Pacific.

Hellenic Shipping (2020). How Covid-19 Ushers New Opportunities in Port Operations. Hutchison Ports (2020). Covid-19 Accelerates Drive for Digitization of Shipping

IAPH - WPSP (2020). Guidance on Ports' response to the Coronavirus Pandemic, Antwerp.

IAPH (2020). Accelerating Digitalization of Maritime trade and logistic: A Call to Action.

Nnamdi, et al. (2020). Nigeria: Embracing Post-pandemic facilities in the Maritime Industry.

Prosertek (2020). 5 Challenges of the Maritime Transport Industry must face due to Covid-19.

PWC Greece (2020). Shipping Industry responding to the Covid-19, keeping the lights on with a response strategy plan.

UNCTAD (2020). Covid-19 and Maritime Transport: Impact and responses

World Bank (2021). Digitalizing the Maritime Sector set to Boost the Competitiveness and Resilience of Global Trade.

Yim Lam (2020). Technology will help Maritime transport navigate through the pandemic and beyond. 
Ikenna Amuka, Ozumba Uzochukwu, Nnamdi Chijoke Anyachebelu

Creative Commons licensing terms

Authors will retain copyright to their published articles agreeing that a Creative Commons Attribution 4.0 International License (CC BY 4.0 ) terms will be applied to their work. Under the terms of this license, no permission is required from the author(s) or publisher for members of the community to copy, distribute, transmit or adapt the article content, providing a proper, prominent and unambiguous attribution to the authors in a manner that makes clear that the materials are being reused under permission of a Creative Commons License. Views, opinions and conclusions expressed in this research article are views, opinions and conclusions of the author(s). Open Access Publishing Group and European Journal of Economic and Financial Research shall not be responsible or answerable for any loss, damage or liability caused in relation to/arising out of conflict of interests, copyright violations and inappropriate or inaccurate use of any kind content related or integrated on the research work. All the published works are meeting the Open Access Publishing requirements and can be freely accessed, shared, modified, distributed and used in educational, commercial and non-commercial purposes under a Creative Commons Attribution 4.0 International License (CC BY 4.0). 